\title{
THE INTERRELATIONS OF SERUM LIPIDS IN NORMAL PERSONS ${ }^{1}$
}

\author{
BY JOHN P. PETERS AND EVELYN B. MAN \\ (From the Departments of Internal Medicine and Psychiatry of the Yale University \\ School of Medicine, New Haven)
}

(Received for publication January 26, 1943)

All observers ( 1 to 5 ) agree that the concentrations of lipid constituents in the serum of normal individuals vary greatly. In fact, the degree of variability is so great that no significance can be attached to a single observation unless it is extremely abnormal. On the other hand, there is evidence that the degree of variability of certain lipid components-for example, cholesterol-in a given normal person, is far more restricted (4 to 7). Furthermore, the relative proportions of certain of the constituents-for example, the ratio of free to total cholesterol-are quite constant, not only in a given individual, but also in the population at large $(4,8)$. A large series of measurements of serum lipids from normal persons and patients has, therefore, been analyzed, in an effort to discover criteria which may permit more accurate evaluation of such measurements in pathologic or disturbed physiologic states.

\section{MATERIAL AND METHODS}

The material consists of a large number of measurements of lipids in sera, collected during the last 10 years, from normal persons and patients with various diseases. The subjects were all in the postabsorptive state. The clinical material was derived chiefly from the medical and psychiatric services of the New Haven Hospital and Dispensary.

The analytical methods of Man, Gildea, Peters, and Bogdanovitch ( 9 to 13) were employed. In a large proportion of the determinations, cholesterol, total fatty acid, and lipid phosphorus were measured; in a number, however, lipid phosphorus was omitted. In a few instances, both free and total cholesterol were determined; and in a still smaller fraction, iodine numbers were also included. For the last, the procedure of Yasuda (14) was employed.

\section{CALCULATIONS}

Throughout the tables and text, the concentration of each component is expressed in terms related to the method of analysis employed: cholesterol in mgm. per cent, lipid phosphorus in mgm. per cent of phosphorus, and

\footnotetext{
1 This investigation was aided by grants from the Knight Fund and the Fluid Research Fund of the Yale University School of Medicine.
}

fatty acid in m.eq. of fatty acid per liter. In the calculation of free fat, it has been assumed that 28 per cent of cholesterol exists in the free form, 72 per cent as esters, and that 20 per cent of lipid phosphorus belongs to sphingomyelin, the remainder to lecithin and cephalin of the generally accepted composition. Fatty acid combined with cholesterol has, therefore, been estimated by means of the equation,

$$
\begin{aligned}
& \frac{10 \times 0.72 \text { cholesterol (mgm. per cent) }}{386} \\
& =\text { fatty acid (m.eq. per liter) in cholesterol esters, }
\end{aligned}
$$

in which 386 represents the weight of a millimol of cholesterol, 0.72 the average proportion of cholesterol esterified, and 10 converts $\mathrm{mgm}$. per cent to $\mathrm{mgm}$. per liter. Fatty acid in phospholipid has been estimated by the equation,

$$
\begin{gathered}
\frac{10 \times[(0.80 \times 2)+0.20] \text { lipid P (mgm. per cent) }}{31} \\
=\text { phospholipid fatty acid (m.eq. per liter), }
\end{gathered}
$$

in which 31 is the weight of a millimol of phosphorus, 10 converts m.eq. per cent to m.eq. per liter, $(0.80 \times 2)$ represents the fraction of fatty acid combined with lecithin and cephalin, each of which carries 2 equivalents, while 0.20 represents the fraction combined with sphingomyelin which contains only one equivalent of fatty acid.

Sperry (8) found that the ratio of free to total cholesterol in a large series of normals varied only from 0.24 to 0.30 . Brun (4) has reported variations from 0.24 to 0.32 , which agrees with our own experience. The averages in all of the 3 series lay between 0.26 and 0.28 . The maximum error in the calculation of cholesterol fatty acids, by the formula adopted, should not, therefore, exceed 6 per cent.

The relative proportions of phospholipids are less certain. Only a few measurements of the concentration of sphingomyelin in serum have been published, and these differ greatly $(15,16)$. Whether, however, this compound makes up 40 per cent of the phospholipid or is completely absent from serum, the apparent extreme possibilities, the error of estimating phospholipid fatty acids by the formula adopted will not exceed 10 per cent.

Free fat is estimated, in terms of m.eq. of fatty acid per liter, by the formula,

Fat fatty acid = total fatty acid-(Cholesterol ester fatty acid + phospholipid fatty acid).

Being estimated by difference, it is subject to the summated errors of the other calculations. With the factors selected for the calculation of fatty acids of cholesterol esters and phospholipids, only one negative value, -0.3 
m.eq. per liter, for free fat was obtained in the whole series of measurements on normal subjects. This proves that the factors employed are not grossly excessive. Since only one negative value was obtained and since a negative value is impossible, 0 has been used as the minimum in Table $\mathrm{I}$.

\section{EXPERIMENTAL DATA}

The variations of lipid components in the serum of normal individuals in the postabsorptive state are summarized in Table I. In this series, 40 per cent of the subjects were female and 60 per cent male. The ages ranged from 10 to 68 years, although at least 83 per cent were 18 or more years old. All of these individuals were included because analysis of the data from the standpoints of both sex and age revealed no significant deviations. For example, in an age group of 20 through 50 years, the serum cholesterol of 79 males averaged 194 and of 65 females $199 \mathrm{mgm}$. per cent; the serum fatty acids of the males averaged 12.1 and of the females $11.6 \mathrm{~m} . \mathrm{eq}$. In an age group of 10 through 14 years, the serum cholesterol of 9 males averaged 172 and of 8 females, $187 \mathrm{mgm}$. per cent. These averages are not significantly lower than the average for adults because the difference, $26 \mathrm{mgm}$. per cent, does not approach twice the standard deviation from the average of the children's cholesterol. Similarly, the average fatty acid of the children was not significantly lower than that of the adults; the 9 boys had average serum fatty acids of 10.0 and the 8 girls, of $11.1 \mathrm{~m} . e q$. In each instance, the total range-i.e., maximum and minimum values-is derived from all observations. For the estimation of means and standard devia- tions of all components except total fatty acids, however, averages of multiple determinations have been used, so that each individual appears but once. For example, cholesterol was measured 312 times in serum from 174 subjects; there were 34 observations on one subject, 28 on another. Obviously, if all these were included, the results might be unduly weighted. Therefore, when multiple observations were made upon any individual, an average was taken for statistical treatment.

In the estimation of the mean free fat of 102 individuals, the 3 highest figures were omitted because they diverged from the other analyses by more than twice the standard deviation, being altogether anomalous. These will be discussed further below.

Free fat is by all odds the most variable of the 3 fractions, the standard deviation amounting to 48 per cent of the mean. This must be discounted somewhat because calculation of free fat by difference permits a summation of errors. The deviations in certain instances, however, are altogether too gross to be attributed to errors of either analysis or calculation. The standard deviations of cholesterol and lipid phosphorus have approximately the same order of magnitude, 18 and 15 per cent of the mean, respectively.

Table II gives the average values and the range of variation of lipids in normal individuals on whom multiple observations were made. If this table is compared with Table $\mathrm{I}$, it is at once apparent that the degree of variability of all lipids in a given normal subject is far smaller than that of a group of individuals. Each person has a

TABLE I

Lipids of normal serum

\begin{tabular}{|c|c|c|c|c|c|}
\hline Substance & $\begin{array}{l}\text { Number of } \\
\text { observations }\end{array}$ & $\begin{array}{l}\text { Maxi- } \\
\text { mum }\end{array}$ & $\begin{array}{l}\text { Mini- } \\
\text { mum }\end{array}$ & Mean & S.D. \\
\hline $\begin{array}{l}\text { Fatty acids (m.eq. per liter) } \\
\text { Cholesterol, total observations (mgm. per cent) } \\
\text { Cholesterol, individuals (mgm. per cent) }\end{array}$ & $\begin{array}{l}355 \\
312 \\
174\end{array}$ & $\begin{array}{l}36.9 \\
320 \\
320\end{array}$ & $\begin{array}{l}7.3 \\
107 \\
107\end{array}$ & $\begin{array}{r}12.3 \\
202.7 \\
194.1\end{array}$ & $\begin{array}{l} \pm 3.37 \\
\pm 35.6\end{array}$ \\
\hline $\begin{array}{l}\text { Lipid phosphorus, total observations (mgm. per cent) } \\
\text { Lipid phosphorus, individuals (mgm. per cent) }\end{array}$ & $\begin{array}{l}213 \\
108\end{array}$ & $\begin{array}{l}14.5 \\
14.5\end{array}$ & $\begin{array}{l}6.1 \\
6.1\end{array}$ & $\begin{array}{l}9.60 \\
9.21\end{array}$ & \pm 1.41 \\
\hline $\begin{array}{l}\text { Ratio, cholesterol : lipid P, total observations } \\
\text { Ratio, cholesterol : lipid P, individuals }\end{array}$ & $\begin{array}{l}214 \\
103\end{array}$ & $\begin{array}{l}31.7 \\
31.7\end{array}$ & $\begin{array}{l}14.9 \\
14.9\end{array}$ & $\begin{array}{l}21.53 \\
21.36\end{array}$ & \pm 2.48 \\
\hline $\begin{array}{l}\text { Free fat, total observations (m.eq. per liter) } \\
\text { Free fat, individuals (m.eq. per liter) }\end{array}$ & $\begin{array}{c}209 \\
102 \\
99^{*}\end{array}$ & $\begin{array}{r}17.8 \\
17.8 \\
9.3\end{array}$ & $\begin{array}{l}\mathbf{0} \\
\mathbf{0} \\
\mathbf{0}\end{array}$ & $\begin{array}{l}4.26 \\
4.05 \\
3.12\end{array}$ & \pm 1.49 \\
\hline
\end{tabular}

* Three observations were excluded in the calculation because they exceeded the mean of the total number by more than twice the standard deviation. 
TABLE II

The variability of serum lipids in normal individuals

\begin{tabular}{|c|c|c|c|c|c|c|c|c|c|c|c|c|c|c|}
\hline \multirow{2}{*}{ Subject } & \multicolumn{2}{|c|}{ Determinations } & \multicolumn{3}{|c|}{ Cholesterol } & \multicolumn{3}{|c|}{ Lipid phosphorus } & \multicolumn{3}{|c|}{ Free fat fatty acids } & \multicolumn{3}{|c|}{ Cholesterol : Lipid P } \\
\hline & $\underset{\text { ber }}{\text { Num- }}$ & $\underset{\text { tion }}{\text { Dura- }}$ & $\begin{array}{l}\text { Maxi- } \\
\text { mum }\end{array}$ & $\begin{array}{l}\text { Mini- } \\
\text { mum }\end{array}$ & $\underset{\text { age }}{\text { Aver- }}$ & $\begin{array}{l}\text { Maxi- } \\
\text { mum }\end{array}$ & $\begin{array}{l}\text { Mini- } \\
\text { mum }\end{array}$ & $\begin{array}{c}\text { Aver- } \\
\text { age }\end{array}$ & $\underset{\text { maxi- }}{\text { Mam }}$ & $\begin{array}{l}\text { Mini- } \\
\text { mum }\end{array}$ & $\underset{\text { age }}{\text { Aver- }}$ & $\underset{\text { maxi- }}{\text { Maxi }}$ & $\begin{array}{l}\text { Mini- } \\
\text { mum }\end{array}$ & $\begin{array}{c}\text { Aver- } \\
\text { age }\end{array}$ \\
\hline & & months & \multicolumn{3}{|c|}{ mgm. per $100 \mathrm{cc}$. } & \multicolumn{3}{|c|}{ mgm. per $100 \mathrm{cc}$. } & \multicolumn{3}{|c|}{ m.eq. per liter } & & & \\
\hline $\begin{array}{l}\text { EBM } \\
\text { EFG } \\
\text { WB } \\
\text { MG } \\
\text { Rom. } \\
\text { Ar. } \\
\text { AWO } \\
\text { SCH } \\
\text { VM } \\
\text { CLR } \\
\text { Ko. } \\
\text { Da. } \\
\text { PMH } \\
\text { PHL } \\
\text { WM } \\
\text { AW } \\
\text { Sp. }\end{array}$ & $\begin{array}{r}34 \\
28 \\
12 \\
9 \\
8 \\
7 \\
5 \\
3 \\
3 \\
3 \\
2 \\
2 \\
2 \\
2 \\
2 \\
2 \\
2\end{array}$ & $\begin{array}{r}45 \\
30 \\
56 \\
12 \\
6 \\
2 \\
15 \\
1 \\
5 \\
53 \\
6 \\
2 \\
29 \\
59 \\
3 \\
1 \\
0.5\end{array}$ & $\begin{array}{l}252 \\
239 \\
229 \\
179 \\
157 \\
265 \\
320 \\
215 \\
241 \\
258 \\
225 \\
213 \\
241 \\
283 \\
250 \\
204 \\
144\end{array}$ & $\begin{array}{l}198 \\
173 \\
185 \\
154 \\
128 \\
240 \\
197 \\
160 \\
219 \\
216 \\
210 \\
209 \\
215 \\
199 \\
248 \\
198 \\
134\end{array}$ & $\begin{array}{l}218 \\
214 \\
213 \\
169 \\
152 \\
248 \\
265 \\
189 \\
234 \\
232 \\
218 \\
211 \\
228 \\
241 \\
249 \\
201 \\
139\end{array}$ & $\begin{array}{r}11.3 \\
11.2 \\
10.2 \\
11.4 \\
9.4 \\
11.3 \\
14.5 \\
8.2 \\
10.0 \\
10.4 \\
10.0 \\
10.9 \\
10.8 \\
11.8 \\
11.4 \\
12.5 \\
8.1\end{array}$ & $\begin{array}{r}8.9 \\
8.7 \\
8.4 \\
8.7 \\
7.8 \\
9.9 \\
10.0 \\
7.6 \\
9.2 \\
9.7 \\
8.2 \\
9.5 \\
9.8 \\
8.4 \\
10.8 \\
11.2 \\
6.7\end{array}$ & $\begin{array}{r}10.9 \\
9.9 \\
9.5 \\
9.9 \\
8.7 \\
10.5 \\
13.0 \\
7.8 \\
9.7 \\
10.2 \\
9.1 \\
10.2 \\
10.3 \\
10.1 \\
11.1 \\
11.9 \\
7.4\end{array}$ & $\begin{array}{r}3.6 \\
8.7 \\
4.4 \\
3.4 \\
2.4 \\
3.5 \\
22.9 \\
4.0 \\
2.2 \\
6.0 \\
4.4 \\
1.9 \\
3.6 \\
5.6 \\
2.4 \\
8.4 \\
7.4\end{array}$ & $\begin{array}{l}0.4 \\
1.6 \\
1.6 \\
0.1 \\
1.1 \\
2.5 \\
5.3 \\
3.1 \\
1.0 \\
2.5 \\
4.3 \\
1.5 \\
1.1 \\
3.7 \\
1.8 \\
6.1 \\
2.8\end{array}$ & $\begin{array}{r}1.9 \\
3.0 \\
2.7 \\
1.8 \\
1.7 \\
3.0 \\
17.2 \\
3.5 \\
1.6 \\
4.0 \\
4.4 \\
1.7 \\
2.4 \\
4.7 \\
2.1 \\
7.3 \\
5.2\end{array}$ & $\begin{array}{l}25.1 \\
24.5 \\
24.2 \\
19.3 \\
24.0 \\
26.1 \\
22.1 \\
26.2 \\
24.6 \\
24.8 \\
27.4 \\
22.0 \\
22.3 \\
24.0 \\
23.0 \\
17.7 \\
20.0\end{array}$ & $\begin{array}{l}18.4 \\
17.4 \\
20.7 \\
14.9 \\
20.0 \\
21.2 \\
17.8 \\
21.1 \\
23.8 \\
21.7 \\
21.0 \\
19.5 \\
21.9 \\
23.7 \\
21.9 \\
16.3 \\
17.8\end{array}$ & $\begin{array}{l}21.6 \\
21.8 \\
22.5 \\
17.2 \\
22.0 \\
23.6 \\
20.4 \\
24.1 \\
24.2 \\
22.9 \\
24.2 \\
20.8 \\
22.1 \\
23.9 \\
22.5 \\
17.0 \\
18.8\end{array}$ \\
\hline
\end{tabular}

characteristic average concentration of cholesterol. Although this varies from time to time, it does not depart radically from the mean, even over periods of years. For example, over periods of from 6 to 12 months, the cholesterols of MG and Rom, which are low, never overlap those of WB and AWO, which are consistently high. This has already been pointed out ( 5 to 7 ) with respect to cholesterol. It is evident from Table II that it is equally true of lipid phosphorus, but holds only to a slight degree for free fat.

Examination of Table II reveals also that the concentration of lipid phosphorus tends to follow quite closely that of cholesterol; when one is high, the other tends also to be elevated. From Table I, it may be seen that the ratio of cholesterol to lipid phosphorus is more constant than is the concentration of either component, having a standard deviation of only 12 per cent of the mean. McQuarrie and Bloor $(17,18)$ and Man, Peters, and Gildea (19 to 22) have already called attention to the correlation between cholesterol and lipid phosphorus.

More minute analysis of the data reveals that the ratio of cholesterol to lipid phosphorus tends to vary with the concentration of cholesterol (see Table III). The mean ratio in 38 observations on normal persons, with cholesterol between 100

TABLE III

Relation of serum cholesterol to ratio, cholesterol : lipid phosphorus $(R)$

\begin{tabular}{|c|c|c|c|c|c|c|c|c|c|c|c|c|}
\hline \multirow{2}{*}{ Condition } & \multirow{2}{*}{$\begin{array}{c}\text { Number } \\
\text { of } \\
\text { observa- } \\
\text { tions }\end{array}$} & \multicolumn{2}{|c|}{ Cholesterol } & \multirow{2}{*}{$\mathbf{R}$} & \multirow{2}{*}{$\begin{array}{c}\text { Number } \\
\text { of } \\
\text { observa- } \\
\text { tions }\end{array}$} & \multicolumn{2}{|c|}{ Cholesterol } & \multirow{2}{*}{$\mathbf{R}$} & \multirow{2}{*}{$\begin{array}{c}\text { Number } \\
\text { of } \\
\text { observa- } \\
\text { tions }\end{array}$} & \multicolumn{2}{|c|}{ Cholesterol } & \multirow{2}{*}{$\mathbf{R}$} \\
\hline & & Range & $\begin{array}{c}\text { Aver- } \\
\text { age }\end{array}$ & & & Range & $\begin{array}{c}\text { Aver- } \\
\text { age }\end{array}$ & & & Range & $\begin{array}{c}\text { Aver- } \\
\text { age }\end{array}$ & \\
\hline $\begin{array}{l}\text { Normal } \\
\text { Psychiatric } \\
\text { Normal and psychiatric } \\
\text { Thyroid disease } \\
\text { Obesity }\end{array}$ & $\begin{array}{r}38 \\
23 \\
61 \\
132 \\
12\end{array}$ & $\begin{array}{c}\text { mgm. per } \\
<180 \\
<180 \\
<180 \\
<180 \\
<180\end{array}$ & 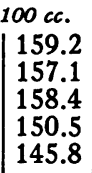 & $\begin{array}{l}20.3 \\
19.2 \\
20.0 \\
18.6 \\
19.9\end{array}$ & $\begin{array}{r}51 \\
52 \\
103 \\
106 \\
17\end{array}$ & $\begin{array}{c}\text { mgm. per } \\
180-239 \\
180-239 \\
180-239 \\
180-239 \\
180-239\end{array}$ & $\begin{array}{l}100 c c . \\
\mid \begin{array}{l}204.6 \\
203.3 \\
204.0 \\
205.9 \\
202.4\end{array}\end{array}$ & $\begin{array}{l}21.6 \\
21.4 \\
21.5 \\
21.3 \\
21.9\end{array}$ & $\begin{array}{r}14 \\
15 \\
29 \\
85 \\
2\end{array}$ & $\begin{array}{c}\text { mgm. per } \\
>239 \\
>239 \\
>239 \\
>239 \\
>239\end{array}$ & $\begin{array}{l}100 c c . \\
\begin{array}{|l|}257.1 \\
261.0 \\
259.1 \\
272.0 \\
270.0\end{array}\end{array}$ & $\begin{array}{l}23.6 \\
24.0 \\
23.8 \\
23.6 \\
24.2\end{array}$ \\
\hline Malnutrition & $\begin{array}{l}40 \\
12\end{array}$ & $\begin{array}{c}100-179 \\
<100\end{array}$ & \begin{tabular}{|r|}
141.7 \\
75.2
\end{tabular} & $\begin{array}{l}18.7 \\
13.8\end{array}$ & $\begin{array}{l}17 \\
24\end{array}$ & $\underset{100-149}{>}$ & \begin{tabular}{|l|}
206.8 \\
123.2
\end{tabular} & $\begin{array}{l}21.2 \\
17.9\end{array}$ & 23 & $150-199$ & 173.7 & 19.8 \\
\hline Thyroid disease & $\begin{array}{r}4 \\
80 \\
4\end{array}$ & $\begin{array}{c}<100 \\
200-249 \\
350-400\end{array}$ & $\begin{array}{r}84.4 \\
223.0 \\
380.2\end{array}$ & $\begin{array}{l}14.4 \\
21.5 \\
25.8\end{array}$ & $\begin{array}{r}63 \\
56 \\
8\end{array}$ & $\begin{array}{l}100-149 \\
250-299 \\
400-499\end{array}$ & $\begin{array}{l}133.1 \\
273.4 \\
441.4\end{array}$ & $\begin{array}{l}17.4 \\
24.0 \\
27.4\end{array}$ & $\begin{array}{r}102 \\
19 \\
6\end{array}$ & $\begin{array}{l}150-199 \\
300-339 \\
532-911\end{array}$ & $\begin{array}{l}175.4 \\
323.6 \\
638.6\end{array}$ & $\begin{array}{l}20.3 \\
24.1 \\
30.4\end{array}$ \\
\hline
\end{tabular}


and $180 \mathrm{mgm}$. per cent, was 20.3 ; in 51 observations, with cholesterol between 180 and $240 \mathrm{mgm}$. per cent, it was 21.6 ; and in 14 observations, with cholesterol between 240 and 320 mgm. per cent, it was 23.6.

Attention has already been called to the constancy of the ratio of free to total cholesterol and its independence of the total concentration of cholesterol. In this series, in 19 observations on normal individuals, the ratio varied from 0.24 to 0.32 , with an average of 0.28 .

Iodine numbers were determined on 11 occasions in 6 individuals. They varied from 100 to 137, averaging 120 . The number of observations is too small to warrant analysis of the relation of these variations to other features of the lipid patterns.

\section{DISCUSSION}

The range of concentration of cholesterol in this series agrees with reports of other competent observers $(4,5,7,8,17)$. There are less data available dealing with lipid phosphorus of adults. Boyd's figures (3) are of the same general order of magnitude. But McQuarrie, Bloor, Husted, and Patterson (17) reported 88 to $261 \mathrm{mgm}$. per cent of "lecithin," with a mean of 172 , in the sera of "32 essentially normal persons" from 8 to 18 years of age. This would be equivalent to from 3.8 to $10.4 \mathrm{mgm}$. per cent of lipid phosphorus, with a mean of 6.7 , figures distinctly lower than either Boyd's or ours. Values for free fat in the literature are extremely variable. The differences depend largely upon the quantities of fatty acid accredited to phospholipid and cholesterol esters. Boyd (3) and McQuarrie, Bloor, et al. (17) found average concentrations of total fatty acid similar to those found in this study, but their estimates of free fat are greater than our own because they obtained smaller amounts of phospholipid and cholesterol esters.

For the extreme variability of the lipids in presumably normal individuals, there is as yet no adequate explanation. In males, Gildea, Kahn, and Man (23) noted a rough correlation with body build. In men of the "pyknophilic" type, cholesterol tended to be high, while in leptosomes, it was low. In females, however, no similar correlation could be established. This discrepancy is susceptible of many interpretations. The deter- minants of serum lipids in the two sexes may be fundamentally different. On the other hand, the true determinant may have been confused with coincidentally variant structural features in the male. Sperry (5) detected no relation between cholesterol and body build; but admits that his subjects were not scrutinized from this point of view. The matter requires more intense analysis. Meanwhile, the observation of Gildea, Kahn, and Man permits data from males to be evaluated with a degree of discrimination that cannot be attained with data from females, although the range of variation is the same for both sexes.

Cholesterol does not parallel weight consistently, nor is obesity related to hypercholesterolemia. The lipids of a group of obese adults lay in every respect within the normal range and were as often low as high (see Table III). The serum lipids of 34 obese children, aged 9 through 14 years, did not differ from those of 17 normal children, 4 through 14 years of age. When more than one determination was made on these subjects, no direct relation could be discovered between weight and cholesterol. In contrast to this, certain normal males with a tendency to obesity exhibited the highest degree of variation of cholesterol encountered in the normal group. These individuals had high cholesterol and lipid phosphorus. An example is shown in AWO, Figure 1. The variations in these subjects cannot be regarded as altogether accidental. The highest cholesterols coincide with periods of excessive weight; the lowest occur immediately after strenuous efforts to reduce weight by dietary measures.

Man and Gildea (21) have reported that, in contrast to mere thinness, malnutrition causes both cholesterol and lipid phosphorus to fall, roughly in the same proportions. The large decreases of lipids that followed rigorous dietary restriction may denote losses of something more than fatty tissue, creating a condition akin to malnutrition in the face of obesity. The diets may have been unbalanced, thereby modifying the nature of the metabolic mixture. One normal subject reduced his weight from 215 to 198 pounds in 25 days. At the same time, his cholesterol fell from 215 to 160 and lipid phosphorus from 8.2 to $7.6 \mathrm{mgm}$. per cent. In the next 11 days, while his weight fell 2 more pounds, to 196 , the cholesterol reverted to 192, lipid phosphorus only to $7.7 \mathrm{mgm}$. per cent. 

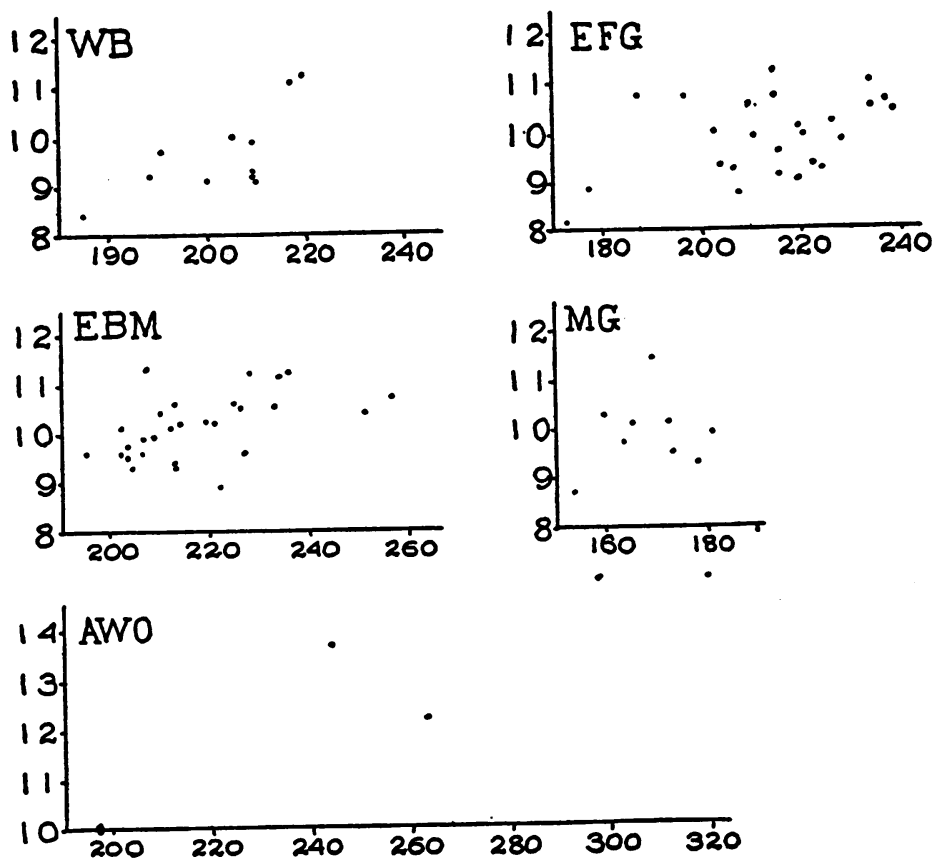

Fig. 1. The Relation of Cholesterol to Lipid Phosphorus in Representative Normal Individuals

Ordinates in each case represent lipid phosphorus, abscissae, cholesterol, both expressed in mgm. per cent.

Comparable phenomena were observed in 2 or 3 other subjects, under similar circumstances.

Although serum cholesterol is frequently resistant to the immediate effects of food, it does not appear to be altogether unaffected by diet-or perhaps it would be more correct to say to the state of fat metabolism. Slight rises have been noted by Man (24) in a certain proportion of normal adults after variable periods of starvation. In diabetic acidosis, far greater changes are observed. Serum cholesterol is altered when "dietary fatty livers" occur. Variations of major magnitude were induced by radical changes of diet by McQuarrie, Husted, and Bloor (18). In one instance, on a diet consisting of protein and fat without carbohydrate, serum cholesterol rose in 5 days from 102 to $208 \mathrm{mgm}$. per cent. Steiner and Domanski (25) found increases in serum cholesterol of from 50 to $218 \mathrm{mgm}$. per cent in 10 patients who were given 100 grams of egg yolk powder, in addition to a high caloric diet, for 6 to 10 weeks. Turner and Steiner (7) observed a slight rise of dubious significance in the serum cholesterol of 4 of 9 patients given a high fat diet for 6 weeks.
The ratio of cholesterol to lipid phosphorus appears to be more constant than the concentration of either of the fractions of which it is composed. In a large series of patients with psychiatric disorders, the lipid patterns did not depart significantly from the normal although the concentrations of lipids were more variable, presumably because of the extreme diversity of activity and diet associated with excessive mood swings. Low cholesterol which was particularly common was regularly accompanied by a reduction of lipid phosphorus and of the ratio of cholesterol to lipid phosphorus. This ratio in a group of malnourished persons diminished rapidly when cholesterol fell below the normal range. When malnutrition was overcome, cholesterol, lipid phosphorus, and the ratio rose together. If they were initially subnormal, they returned to normal; if they were initially within normal limits, they rose further, following in each case approximately the curve describing variations in the normal group.

This correlation, while easily demonstrable in the series as a whole, is not so consistently discernible in multiple observations on single individuals. This can be seen from Figures 1 and 2 

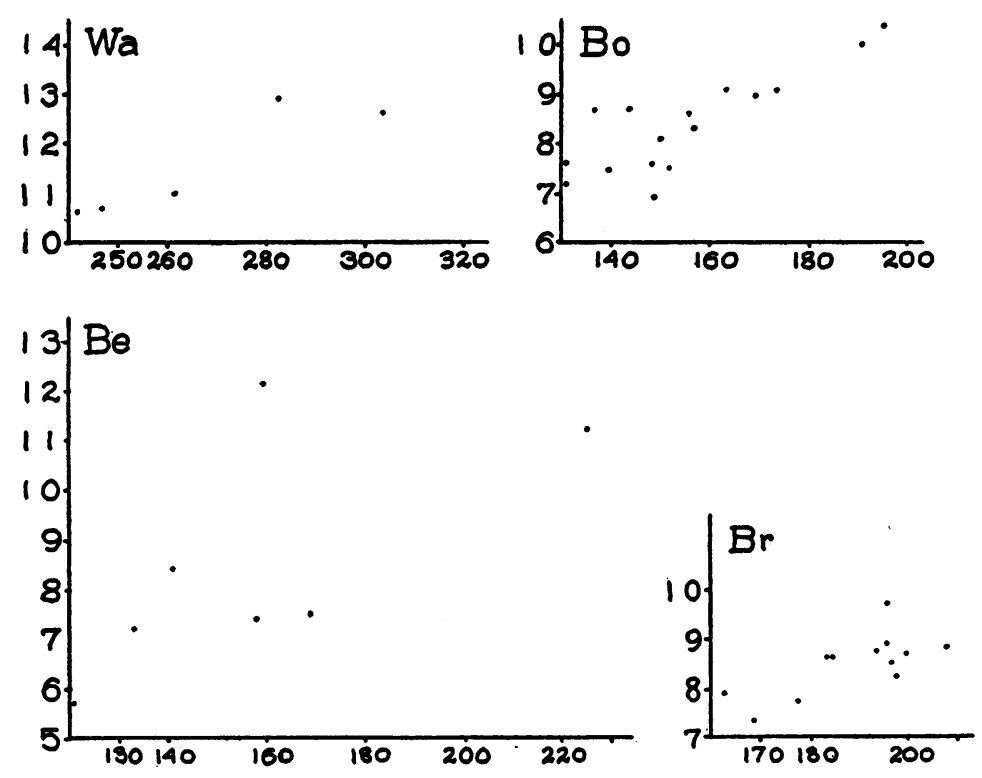

Fig. 2. The Relation of Cholesterol to Lipid Phosphorus in Representative Psychiatric Patients

Ordinates in each case represent lipid phosphorus, abscissae, cholesterol, both expressed in mgm. per cent.

in which are depicted repeated measurements upon a representative group of normal and psychiatric patients. In the majority, there is a tendency for cholesterol and lipid phosphorus to vary together, which is more conspicuous in some than in others. In almost all, the lowest cholesterols coincide with the lowest, and the highest cholesterols with the highest, lipid phosphoruses, with scattering in the intermediate ranges. In only a few is the correlation so bad as it is in MG, Figure 1. In some,e.g., $\mathrm{WB}$ and $\mathrm{AWO}$, Figure 1 , and $\mathrm{Br}, \mathrm{Wa}$, and Bo, Figure 2-it is surprisingly good. Within the comparatively narrow confines of normal variability, each lipid component appears to enjoy freedom of independent motion. The impression is derived that minor variations of individual lipids may be determined by a number of factors which obscure the predominant associations evident in the series as a whole. In most of the normals, the total range of variation is so small that it is impossible by casual observation to identify the factors responsible for deviations from the usual lipid patterns.

The ratio, cholesterol: lipid phosphorus, tended to vary directly with the concentration of cholesterol. The degree of variation in normal subjects was so small that its significance might be doubted were it not that the same trend is discernible when individuals are compared (see Table II) and in other series of cases, in which cholesterol varies over a wider range (see Table III). Somewhat similar relations are evident in data of McQuarrie, Husted, and Bloor (18), though they attached to them a different interpretation. In a study of epileptics, they noted that the ratio of cholesterol to lipid phosphorus was extremely variable. These variations they connected with the epileptiform state. The ratios, however, actually tend to vary with the concentration of cholesterol. This is particularly striking in the cases shown in their Tables 4 and 6, since in these cases, the fluctuations of cholesterol, which occurred in response to alterations of diet, were especially large. These observations and a study of patients with thyroid disease, which will be presented separately, indicate that the systematic variation of the cholesterol: lipid phosphorus ratio with the concentration of cholesterol found in normal subjects is significant. They also suggest that while cholesterol and lipid phosphorus are little altered by the simple feeding of fat, they are subject to dietary influences. The dietary features which affect them 
have not yet been precisely defined. In their responses to diet, the 2 lipid fractions tend to maintain a consistent relationship.

Although cholesterol is closely correlated with lipid phosphorus, its relation to neutral fat is a loose one. The common statement that fat and lipid phosphorus tend to parallel one another is based largely on measurements of total fatty acids. Since the major part of the fatty acid of blood serum belongs to cholesterol esters and phospholipids, fatty acid will necessarily appear to vary with these fractions, even if neutral fat pursues an entirely independent course. Extremely low values for neutral fat (less than 1 m.eq. per liter) were usually associated with low cholesterol; extremely high values (more than 6 m.eq. per liter) were encountered only in subjects with high cholesterol. Intermediate concentrations of free fat were observed at all levels of cholesterol. The unusually high fat concentrations did not occur in the general run of subjects with high cholesterol, but seemed to be idiosyncrasies which distinguished certain members of this group. In all other respects, these persons appeared to be normal. It is hardly surprising that neutral fat should vary more than cholesterol and lipid phosphorus, since it is the fraction that is chiefly affected by meals (27).

Cholesterol was fractionated 191 times in 146 subjects. Although the material for these studies was selected predominantly from patients who might be expected to have abnormal cholesterol partitions, it was sufficiently diverse to warrant some general deductions. In only 59 instances, in 39 subjects, did the ratio of free to total cholesterol depart from the normal limits of 0.24 to 0.32 and only 43 ratios fell above 0.34 or below 0.22. Among these the ratio was too high 39 times, too low only 4 times. A relative excess of free cholesterol was far more frequent than an unduly large proportion of esters. In all but 2 cases, the abnormal ratios were found in patients with demonstrated or presumptive diseases or disorders of the liver. The exceptions were a schizophrenic and an obese child with mental deficiency.

\section{SUMMARY AND CONCLUSIONS}

An analysis has been made of a large number of measurements of the lipids in the serum of normal individuals in the postabsorptive state. In most instances, cholesterol, lipid phosphorus, and total fatty acids were measured, permitting the estimation of free fat by difference. On a few occasions, cholesterol partitions were carried out, and more rarely, iodine numbers were determined.

The range of variation of all lipid fractions in the whole series was great : from 107 to $320 \mathrm{mgm}$. per cent for cholesterol, from 6.1 to $14.5 \mathrm{mgm}$. per cent for lipid phosphorus, and from 0 to 17.8 m.eq. per liter for fatty acids of free fat, free fat varying most and lipid phosphorus least. There is no distinction between the serum lipids of normal male and female adults. The serum lipids of obese adults and children are indistinguishable from those of normally nourished persons.

The ratio of cholesterol to lipid phosphorus is more constant than either of the functions of which it is composed. The standard deviation of this ratio from its mean in this series was only \pm 12 per cent. The ratio tends to vary also directly with the concentration of cholesterol.

The ratio of free to total cholesterol is as constant in this series as it has been reported by previous observers, varying only from 0.24 to 0.32 , with an average of 0.28 .

Free fat is not definitely correlated with either cholesterol or lipid phosphorus.

A study of the course and the interrelationships of the lipids in disease should be more informative than single observations of any one of the lipid components.

\section{BIBLIOGRAPHY}

1. Bloor, W. R., The distribution of the lipoids ("fat") in human blood. J. Biol. Chem., 1916, 25, 577.

2. Hiller, A., Linder, G. C., Lundsgaard, C., and Van Slyke, D.D., Fat metabolism in nephritis. J. Exper. Med., 1924, 39, 931.

3. Boyd, E. M., Lipid composition of blood in new-born infants. Am. J. Dis. Child., 1936, 52, 1319.

4. Brun, G., Changes in the Lipide Contents of Serum in Patients with Manic-Depressive Psychosis. H. K. Lewis, London, 1940.

5. Sperry, W. M., The concentration of total cholesterol in the blood serum. J. Biol. Chem., 1937, 117, 391.

6. Man, E. B., and Gildea, E. F., Variations in lipemia of normal subjects. J. Biol. Chem., 1937, 119, 769.

7. Turner, K. B., and Steiner, A., A long term study of the variation of serum cholesterol in man. $J$. Clin. Invest., 1938, 18, 45.

8. Sperry, W. M., The relationship between total and 
free cholesterol in human blood serum. J. Biol. Chem., 1936, 114, 125.

9. Man, E. B., and Gildea, E. F., A modification of the Stoddard and Drury titrimetric method for the determination of the fatty acids in blood serum. J. Biol. Chem., 1932, 99, 43.

10. Man, E. B., and Gildea, E. F., Notes on the extraction and saponification of lipids from blood and blood serum. J. Biol. Chem., 1937, 122, 77.

11. Man, E. B., and Peters, J. P., Gravimetric determination of serum cholesterol adapted to the Man and Gildea fatty acid method, with a note on the estimation of lipoid phosphorus. J. Biol. Chem., 1933, $101,685$.

12. Man, E. B., A note on the stability and quantitative determination of phosphatides. J. Biol. Chem., 1937, 117, 183.

13. Bogdanovitch, S. B., and Man, E. B., The effects of castration, theelin, testosterone and antuitrin-S on the lipoids of blood, liver and muscle of guinea pigs. Am. J. Physiol., 1938, 122, 73.

14. Yasuda, M., The determination of the iodine number of lipids. J. Biol. Chem., 1931, 94, 401.

15. Hunter, F. E., Occurrence of sphingomyelin in tissues of the cat. J. Biol. Chem., 1942, 144, 439.

16. Erickson, B. N., Arvin, I., Teague, D. M., and Williams, H. H., Micromethods for the determination of sphingomyelin and choline. Applications for the estimation of the phospholipid partition (sphingomyelin, lecithin, and cephalin) in blood and tissues. J. Biol. Chem., 1940, 135, 671.

17. McQuarrie, I., Bloor, W. R., Husted, C., and Patterson, H. A., The lipids of the blood plasma in epi- lepsy. I. A statistical study of single determinations in 100 epileptic and 32 "normal" subjects. J. Clin. Invest., 1933, 12, 247.

18. McQuarrie, I., Husted C., and Bloor, W. R., The lipids of the blood plasma in epilepsy. II. Variations of lipids in relation to occurrence of seizures. Ibid., 255.

19. Gildea, E. F., Man, E. B., and Peters, J. P., Serum lipoids and proteins in hypothyroidism. J. Clin. Invest., 1939, 18, 739.

20. Man, E. B., Gildea, E. F., and Peters, J. P., Serum lipoids and proteins in hyperthyroidism. J. Clin. Invest., 1940, 19, 43.

21. Man, E. B., and Gildea, E. F., Serum lipoids in malnutrition. J. Clin. Invest., 1936, 15, 203.

22. Man, E. B., and Peters, J. P., Serum lipoids in diabetes. J. Clin. Invest., 1935, 14, 579.

23. Gildea, E. F., Kahn, E., and Man, E. B., The relationship between body build and serum lipoids and a discussion of these qualities as pyknophilic and leptophilic factors in the structure of the personality. Am. J. Psychiat., 1936, 92, 1247.

24. Man, E. B., Unpublished studies.

25. Steiner, A., and Domanski, B., Dietary hypercholesterolemia. Am. J. Med. Sci., 1941, 201, 820.

26. Corcoran, A. C., and Rabinowitch, I. M., A study of the blood lipoids and blood protein in Canadian eastern Arctic Eskimos. Biochem. J., 1937, 31, 343. 343.

27. Man, E. B., and Gildea, E. F., The effect of the ingestion of a large amount of fat and of a balanced meal on the blood lipids of normal man. J. Biol. Chem., 1932, 99, 61. 